\title{
PHACE syndrome in a child with segmental IH of face
}

\author{
Carolina Vasconcelos Guimarães, ${ }_{1}^{1}$ Inês Candeias, ${ }^{1}$ Ana Pinheiro, ${ }^{1}$ Felicidade Trindade ${ }^{2}$
}

${ }^{1}$ Unidade Funcional de Pediatria, Hospital de Cascais, Cascais, Portugal

${ }^{2}$ Unidade Funcional de Dermatologia, Hospital de Cascais, Cascais, Portugal

Correspondence to Dr Carolina

Vasconcelos Guimarães, carolinavguimaraes@gmail.com

Accepted 12 September 2017

\section{DESCRIPTION}

An 8-month-old female infant was referred for paediatric and dermatology consultation for evaluation of a facial haemangioma with progressive growth since the first days of life. The observation showed a large segmental infantile haemangioma (IH) over the right face (figure 1), a small vulvar haemangioma and exotropia of the right eye.

Due to the segmental appearance of the facial IH, we prompted the investigation of PHACE syndrome, an acronym corresponding to a set of alterations: Posterior fossa anomalies, Haemangioma, Arterial lesions, Cardiac abnormalities/coarctation of the aorta alterations and Eye anomalies. ${ }^{1}$

The MR angiography showed an absence of the right internal carotid artery, with circulation assured through the circle of Willis (figure 2). Ophthalmology assessment revealed microphthalmia and retinal vascular abnormalities of the right eye (figure 3). The echocardiogram was normal and an abdominal ultrasound showed a $2 \mathrm{~cm}$ hepatic haemangioma.

The definite diagnosis of PHACE syndrome requires the presence of a haemangioma of the head $>5 \mathrm{~cm}$ in diameter accompanied by one major or two minor criteria. ${ }^{2}$ In our case, the presence of the haemangioma plus two major criteria, agenesis of the right internal carotid artery and retinal vascular abnormalities, confirmed the diagnosis.

On follow-up at 5 years old, the child presents a normal motor and cognitive development, spontaneous regression of the facial and genital haemangiomas and absence of the hepatic haemangioma. She has decreased visual acuity in the right eye.

This case reinforces the importance of early diagnostic suspicion and further investigation in the approach of large segmental IH of the face in infants.

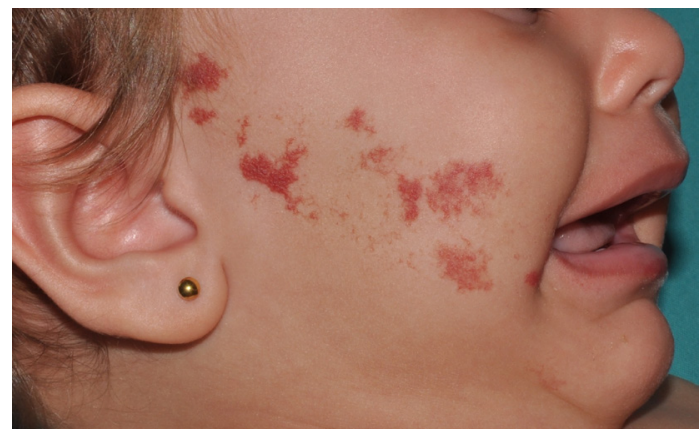

Figure 1 Right facial segmental infantile haemangioma at the level of the mandible, with extension to the lower lip.

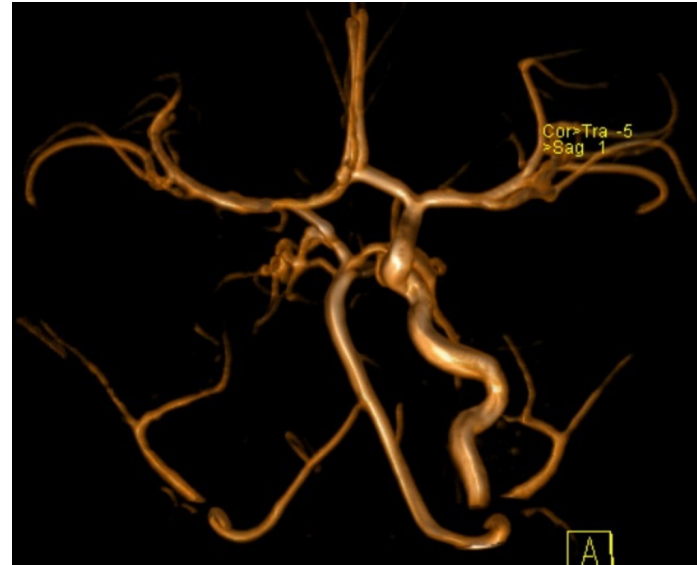

Figure 2 MR angiography: absence of flow of the right internal carotid artery, vestigial right common carotid artery and homolateral external carotid artery.

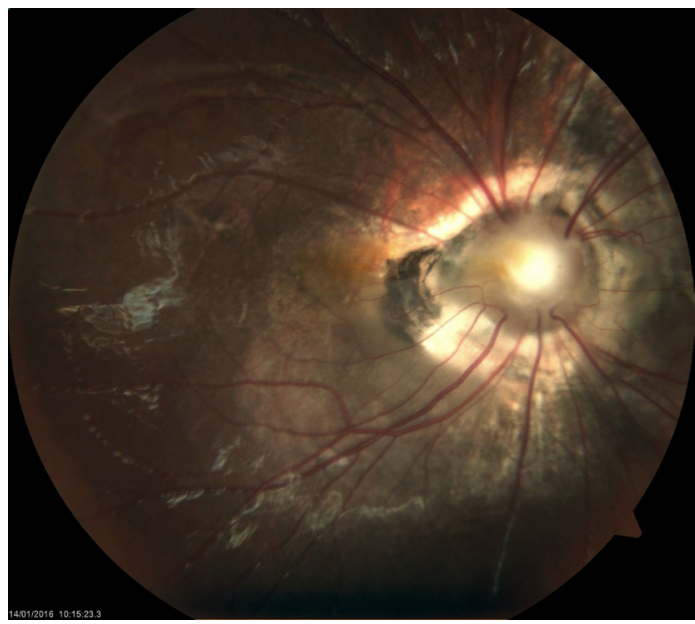

Figure 3 Retinography of the right eye: retinal vascular abnormalities, 'morning-glory'-like.

\section{Learning points}

- In an infant with a large segmental facial haemangioma, it is mandatory to suspect Posterior fossa anomalies, Haemangioma, Arterial lesions, Cardiac abnormalities/ coarctation of the aorta alterations and Eye anomalies (PHACE) syndrome, even if it doesn't look exuberant.

- Brain imaging should always be performed in these cases because most infants with PHACE syndrome don't present with neurological signs or symptoms.

- The neurodevelopment may be compromised but can be entirely normal. 
Contributors CVG participated in the observation of the child and complementary investigation. IC participated in the observation of the child and complementary investigation; was responsible for conception and design of the work, selecting the images and review the text. AP participated in the observation of the child and complementary investigation; was responsible for conception and design of the work, selecting the images and review the text. FT participated in the observation of the child and prompted the complementary investigation; was responsible for conception and design of the work, selecting the images and review the text.

Competing interests None declared.

Patient consent Guardian consent obtained.
Provenance and peer review Not commissioned; externally peer reviewed.

(c) BMJ Publishing Group Ltd (unless otherwise stated in the text of the article) 2017. All rights reserved. No commercial use is permitted unless otherwise expressly granted.

\section{REFERENCES}

1 Metry D, Heyer G, Hess C, et al. Consensus statement on diagnostic criteria for PHACE syndrome. Pediatrics 2009;124:1447-56.

2 Garzon MC, Epstein LG, Heyer GL, et al. PHACE syndrome: consensus-derived diagnosis and care recommendations. J Pediatr 2016;178:24-33.

Copyright 2017 BMJ Publishing Group. All rights reserved. For permission to reuse any of this content visit

http://group.bmj.com/group/rights-licensing/permissions.

BMJ Case Report Fellows may re-use this article for personal use and teaching without any further permission.

Become a Fellow of BMJ Case Reports today and you can:

- Submit as many cases as you like

- Enjoy fast sympathetic peer review and rapid publication of accepted articles

- Access all the published articles

Re-use any of the published material for personal use and teaching without further permission

For information on Institutional Fellowships contact consortiasales@bmjgroup.com

Visit casereports.bmj.com for more articles like this and to become a Fellow 